\title{
EDUKASI GIZI KERJA UNTUK PENINGKATAN PRODUKTIVITAS PADA TENAGA KERJA
}

\section{Anggi Isnani Parinduri ${ }^{1}$, Annisa Febriana Siregar ${ }^{1}$, Raisha Ocktavariny ${ }^{2}$}

${ }^{1}$ Program Studi Gizi Program Sarjana, Institut Kesehatan Medistra Lubuk Pakam ${ }^{2}$ Program Studi Kebidanan Program Sarjana, Institut Kesehatan Medistra Lubuk Pakam

\author{
JIn. Sudirman No.38 LubukPakam, Kabupaten Deli Serdang, \\ Sumatera Utara - Indonesia \\ *email korespondensi author: anggisnani@gmail.com
}

DOI $10.35451 / j p k . v 1 \mathrm{i} 1.718$

\begin{abstract}
Abstrak
Tingkat produktivitas pada tenaga kerja dipengaruhi oleh berbagai hal, salah satu hal yang dapat mempengaruhi produktivitas yaitu asupan zat gizi. Asupan zat gizi akan menghasilkan energi, dimana energi yang dihasilkan dari makanan mampu menentukan kondisi kesehatan dan kemampuan fisik dalam melakukan pekerjaan. Tujuan dari pelaksanaan pengabdian masyarakat untuk mengedukasi tenaga kerja mengenai pentingnya gizi pada pekerja dalam pencapaian tingkat produktivitas yang baik seta pemberian leaflet sebagai bahan bacaan. Pengabdian masyarakat ini dilakukandi PT Pelita Adi Pratama Desa Sei Merbau Tanjung Balai. Pelaksaanaan pengabdian masyarakat ini diawali dengan pemaparan tujuan kegiatan, kemudian dilanjutkan dengan penyampaian materi mengenai edukasi gizi kerja untuk meningkatkan produktivitas tenaga kerja. Setelah penyampaian materi selesai, dilakukan sesi tanya jawab untuk mengevaluasi keberhasilan kegiatan yang telah dilaksanakan.
\end{abstract}

Kata kunci: Edukasi, gizi kerja, tingkat produktivitas

\begin{abstract}
The level of productivity in the workforce is influenced by various things, one of the things that can affect productivity is nutrient intake. Nutrient intake will produce energy, where the energy produced from food is able to determine health conditions and physical ability to do work. The purpose of implementing community service is to educate the workforce about the importance of nutrition for workers in achieving a good level of productivity and providing leaflets as reading material. This community service was carried out at PT Pelita Adi Pratama, Sei Merbau Village, Tanjung Balai. The implementation of this community service begins with the presentation of the objectives of the activity, then continues with the delivery of material on occupational nutrition education to increase labor productivity. After the delivery of the material is complete, a question and answer session is held to evaluate the success of the activities that have been carried out.
\end{abstract}

Keywords: Education, work nutrition, productivity level

\section{Pendahuluan}

Pekerja merupakan salah satu faktor yang berpengaruh pada produksi, disamping faktor lain yang menunjang produksi seperti keterampilan, waktu dan modal yang dimiliki. Sebagai tenaga kerja, memiliki hak yang diatur dalam UU No 13 tahun 2013 tentang Ketenaga kerjaan, diantaranya adalah hak atas kesehatan 
pada diri pekerja. Tenaga kerja merupakan salah satu asset penting yang dibutuhkan perusahan dalam menjalankan aktivitas produksinya. Kesehatan dan tenaga kerja adalah kesatuan yang tidak bisa dipisahkan, salah satunya adalah pemenuhan kebutuhan gizi tenaga kerja yang sesuai dengan status gizi setiap pekerja, beban kerja dalam mencapai dan meningkatkan efesiensi serta tingkat produktivitas tenaga pekerja (Olusegun et al, 2014).

Meningkatkan produktivitas pekerja dapat dipengaruhi oleh beberapa hal, salah satunya ialah dapat dipengaruhi oleh asupan zat gizi seseorang. Asupan zat gizi akan menghasilkan energi, dimana energi yang dihasilkan dari makanan akan menentukan kemampuan fisik dan kondisi kesehatan dalam melakukan pekerjaan. Kebutuhan energi yang tidak terpenuhi akan mengganggu aktivitas pekerja sehingga produktivitas pekerja akan menurun (Ariati, 2013).

Status gizi tenaga kerja sangat berperan penting untuk kesejahteraan dalam meningkatkan keterampilan dan produktivitas. Keadaan gizi dapat ditentukan dari konsumsi makan seseorang. Konsumsi makan seseorang penting untuk meningkat asupan gizi bagi tenaga kerja karena dapat meningkatkan kualitas produktivitas kerjanya (Utami, 2013).

Pekerja yang memiliki status gizi normal lebih memiliki tingkat produktivitas yang baik. Status gizi yang kurus atau gemuk pada pekerja, meskipun persentase yang ditemukan tidak besar tetapi perlu mendapat perhatian. Hal ini menunjukkan bahwa kesehatan dan produktivitas pekerja sangat berhubungan sekali dengan status gizi (Syam, 2013). Konsumsi pangan yang beranekaragam dan seimbang serta peningkatan status gizi yang sesuai merupakan faktor penting dalam meningkatkan kualitas hidup manusia dan akan sangat berpengaruh pada produktivitas pekerja (Aziiza, 2008).

Tenaga kerja dengan status gizi lebih atau obesitas akan lebih lama dan kurang lincah dalam bekerja, hal ini dikarenakan pekerja yang memiliki kelebihan berat badan akan mengeluarkan banyak energi untuk menggerakkan tubuhnya sehingga akan menurunkan tingkat produktivitas perkja, sedangkan orang yang memiliki berat badan normal akan lebih Imudah bergerak dan lebih aktif dalam melakukan pekerjaan sehingga produktivitas kerja akan lebih baik dan seseorang yang memiliki status gizi dengan kategori kurus atau kekurangan berat badan, maka pekerja tersebut akan kurang mampu dalam melakukan pekerjaan yang berat.

Berdasarkan latar belakang diatas maka dilakukanlah pengabdian masyarakat yang bertujuan untuk mengedukasi tenaga kerja mengenai pentingnya gizi pada pekerja dalam pencapaian tingkat produktivitas yang baik.

\section{Metode}

Pengabdian masyarakat ini dilakasanakan dengan metode promotif berupa penyuluhan dengan cara mengedukasi tenaga kerja mengenai gizi untuk peningkatan produktivitas. Kegiatan pengabdian masyarakat ini dilakukan di PT Pelita Adi Pratama Desa Sei Merbau Tanjung Balai pada tanggal 11 Januari 2021. Peserta pada kegiatan pengabdian masyrakat ini berjumlah 20 perkerja.

\section{Hasil dan Pembahasan}

Kegiatan penyuluhan edukasi gizi kerja untuk meningkatkan produktivitas tenaga kerja telah berhasil dilaksanakan. Pelaksaanaan pengabdian masyarakat ini diawali dengan pemaparan tujuan kegiatan, kemudian dilanjutkan dengan penyampaian materi mengenai edukasi gizi kerja untuk meningkatkan produktivitas tenaga kerja. Materi yang sampaikan oleh narasumber meliputi pentingya asupan gizi bagi tenaga kerja, bahaya ketidak cukupan asupan gizi bagi tenaga kerja, contoh menu sehari yang dapat dikonsumsi untuk pekerja dan pentingnya mengoptimalkan status gizi pada tenaga kerja. Setelah materi selesai disampaikan, dilakukan sesi tanya 
Received: 05 June 2021 :: Accepted: 30 June 2021 :: Published: 30 June 2021

jawab untuk mengevaluasi keberhasilan kegiatan yang telah dilaksanakan, kemudian pembagikan leaflet dilakukan sebagai salah satu media yang dugunakan dalam penyuluhan dan sebagai bahan bacaan untuk peserta apabila dalam penyampaian edukasi masih kurang jelas ataupun lupa sehingga peserta dapat membacanya kembali.

Tabel. 1 Gambaran Pengetahuan Gizi Kerja Sebelum Edukasi

\begin{tabular}{ccc}
\hline $\begin{array}{c}\text { Pengetahuan Gizi } \\
\text { Kerja }\end{array}$ & $\mathrm{N}$ & $\%$ \\
\hline Baik & 3 & 15.0 \\
Cukup & 9 & 45.0 \\
Kurang & 8 & 40.0 \\
\hline Jumlah & 20 & 100.0 \\
\hline
\end{tabular}

Dari Tabel.1 diketahui bahwa pengetahuan gizi kerja pada 20 peserta kegiatan pengabdian masyarakat sebelum dilakukan edukasi mayoritas memiliki pengetahuan gizi kerja dengan kategori cukup sebanyak 9 peserta (45\%).

Tabel. 2 Gambaran Pengetahuan Gizi Kerja Sesudah Edukasi

\begin{tabular}{ccc}
\hline $\begin{array}{c}\text { Pengetahuan Gizi } \\
\text { Kerja }\end{array}$ & $\mathrm{N}$ & $\%$ \\
\hline Baik & 10 & 50.0 \\
Cukup & 6 & 30.0 \\
Kurang & 4 & 20.0 \\
\hline Jumlah & 20 & 100.0 \\
\hline
\end{tabular}

Dari Tabel.2 diketahui bahwa pengetahuan gizi kerja pada 20 peserta kegiatan pengabdian masyarakat sesudah dilakukan edukasi masyoritasnya memiliki pengetahuan gizi kerja dengan kategori baik sebanyak 10 peserta (50\%).

Berdasarkan hasil kegiatan sosialisasi yang telah dilakukan diharapkan dapat meningkatkan pengetahuan dan kesadaran para pegawai terhadap pentingnya pengaturan gizi terhadap peningkatan produktivitas kerja. Kegiatan pengabdian kepada masyarakat seperti yang dilakukan berupa pemahaman tentang edukasi gizi seperti pola makan, gizi seimbang dan perilaku hidup bersih dan seimbang. Menurut
Sari dan Muniroh (2017), bahwa terdapat hubungan antara kecukupan asupan gizi serta status gizi dengan kelelahan kerja terhadap pekerja. Jika asupan energi kurang maka tingkat kelelahan kerja meningkat.

\section{Kesimpulan}

Edukasi tentang gizi kerja untuk meningkatkan produktivitas tenaga kerja dan juga dengan pemberian leaflet dapat memberikan wawasan bagi peserta dalam penting pemenuhan asupan gizi dan mengoptimalkan status gizi yang baik. Hal tersebut dapat dilihat dari hasil observasi sebelum dan sesudah dilakukannya edukasi bahwa ada peningkatan pengetahuan peserta sebelum dilakukannya edukasi.

\section{Ucapan Terima Kasih}

Ucapan terima kasih kepada PT. Pelita Adi Pratama Desa Sei Merbau Tanjung Balai, kepada Institut Kesehatan Medistra Lubuk Pakam dan seluruh peserta yang telah membantu dalam melaksanakan kegiatan pengabdian masyarakat.

\section{Daftar Pustaka}

Ariati, N, N. (2013). Gizi Dan Produktifitas Kerja. Jurnal Skala Husada, 10(2), 214-218.

Aziiza, F. (2008). Analisis Aktivitas Fisik, Konsumsi Pangan Dan Status Gizi Dengan Produktivitas Kerja Pekerja Wanita Di Industri Konveksi. Institut Pertanian Bogor.

Olusegun., A. J., Oluwasayo, A. J., \& O. Olawoyin. (2014). An Overview Of The Effects Of Job Stress On Employees Performances In Nigeria Tertiary Hospitals. Journal For Economic Theory And Practice And Social Issues 62.

Sari, R, A \& Muniroh, L. (2017). Hubungan Kecukupan Asupan Energi Dan Status Gizi Dengan Tingkat Kelelahan Kerja Pekerja Bagian Produksi (Studi Di Pt. Multi Aneka Pangannusantara Surabaya). AMERTA NUTR, 275281. 
$================================$

Received: 05 June 2021 :: Accepted: 30 June 2021 :: Published: 30 June 2021

Syam, F. (2013). Gambaran Asupan Zat Gizi, Status Gizi, Dan Produktivitas Kerja Pada Pekerja Pabrik Kelapa Sawit Bagerpang Estate PT.PP.LONSUM 2013. UNIVERSITAS SUMATERA UTARA.

Utami, S. (2013). Status Gizi, Kebugaran Jasmani Dan Produktifitas Kerja Pada Tenaga Kerja Wanita. J. Kesehat. MASY. 8, 113-120 (2013). 